\title{
Agency as Irony: Akrasia and (In)Action in Antony and Cleopatra and Othello
}

\author{
Rui Carvalho Homem \\ University of Porto, Portugal \\ rchomem@netcabo.pt
}

\begin{abstract}
This paper discusses the matter of agency and intention in Shakespearean tragedy from a perspective defined by akrasia, or the perplexity which is posed by a character who wilfully makes a decision (either for action or passivity) the effect of which is contrary to his/her interests - even when everything (in this case, the dramatic situation) indicates s/he should be aware of its consequences. This discussion explores and questions notions of irony as they have traditionally emerged in tragic theory, and will give particular attention to the imbrications between akrasia, irony and gender typecasting in Othello and Antony and Cleopatra. Indeed, the paper will examine the extent to which akratic traits come to prevail in Shakespeare's delineation of the tragic in these plays, and how such traits also become integral to the playwright's ambivalent positing of gender profiles. These are represented at their clearest through (in)action and its results, as the tragic plot progresses to its outcome.
\end{abstract}

No man voluntarily pursues evil, or that which he thinks to be evil. To prefer evil to good is not in human nature; and when a man is compelled to choose one of two evils, no one will choose the greater when he may have the less.

Plato, Protagoras 358d

A man has practical wisdom not by knowing only but by being able to act; but the incontinent man is unable to act - there is, however, nothing to prevent a clever man from being incontinent; this is why it 
is sometimes actually thought that some people have practical wisdom but are incontinent (...) nor yet is the incontinent man like the man who knows and is contemplating a truth, but like the man who is asleep or drunk.

Aristotle, Ethics VII.10

The sense of a stark mismatch between volition and action, intention and achievement, has traditionally been at the core of western understandings of the major dramatic subgenres -i.e., of the representations of human behaviour that energise comic and tragic plots and have long claimed a supra-individual significance. In comedy, this has usually accompanied a diagnosis of human insufficiency translated into inadequate/incompetent behaviour. At its simplest, such inadequacy has often led to the comic being regarded as equivalent to the risible, and, in rather more elaborate disquisitions (such as Aristotle's in the Poetics), justified the commitment of comedy to representing "characters of a lower type" (Poetics V), demeaned by traits the perception of which determines our own cherished superiority when judging their attempts to enact their desires. In tragedy, the perceived clash more often than not involves a diagnosis of excess in traits (power, persistence, strength of will) that (if mitigated) might secure unqualified success, but in their fullness spell disaster, aided by misjudgement. This fatal mismatch often pits character against circumstance in such terms that both the misjudgement and the outcome appear inevitable, against a background of design. Indeed, this sense of inevitability and overarching design applies irrespective of the dominant cultural rationale that one may invoke for construing a human plight in tragic terms: despite their huge historical and intellectual differences, it informs both that conflation of (pagan) Fortune and divine Providence which so starkly determined the conceptualisation of tragedy within a late medieval mindset ${ }^{1}$, and the 'law of probability or necessity' that Aristotle theorised in the Poetics (VII: 7; 1895: 31).

In this paper I will be focusing, however, on instances in Shakespearean tragedy when that conflict might appear to audiences as indeed avoidable; when characters wilfully make decisions (either for action or passivity) the effect of which is contrary to their interests - even when everything (in this case, the dramatic situation) indicates they should be aware of the odds and consequences. This arguably corresponds, in rough terms, to the perplexity that both Plato and Aristotle discussed as akrasia. Since the concept will here be employed as a heuristic and operative device with which to approach the challenges posed by characterisation in Shakespearean tragedy, I opt to draw on those aspects of Plato's and Aristotle's respective discussions of akrasia that are arguably convergent and complementary, rather than divergent. Particular interest will therefore be taken in Socrates's perception of that unnatural preference (often referred to as 'the Socratic paradox') for 'evil' over 'good', or for the greater over the lesser of two evils, that strikingly foregrounds the "inferiority of a man to himself" (Protagoras $358 / J$ owett 1892: 183); and in the contrast between akratic (often rendered as 'incontinent') and enkratic persons - literally, lacking or having 'mastery', especially over themselves - when faced with the challenges that passions pose to their 
capacity for reason, as posited and discussed by Aristotle in the Ethics (VII. 1-10). Aristotle's understanding that the akratic may have their capacity for rational deliberation impaired by either impetuosity or weakness; and, concomitantly, by an "appetite for pleasure" or by "anger", provides conceptual tools that may prove productive in a discussion of Antony and Cleopatra and Othello. I will also take into consideration the fact that both plays, when their respective strategies for characterisation (for representing ethoi) are discussed from this particular angle, bring, through their female characters, matters of gender (and gender differentiation) into play that were largely absent from the classical framework for the concepts in question.

The opening of Antony and Cleopatra would seem to epitomise an akratic profiling of Antony as a case in which reason, and the capacity for deliberation, is jeopardised by an unchecked and overwhelming appetite for pleasure. Indeed, from the displeased opening interjection, "Nay", to the diagnosis and indictment carried by its closing word, "lust", Philo's ten-line description of "this dotage of our general's" accounts for the decline of the man of action from his performative capacities. Such capacities are troped at their most exalted in the enactment of Antony's will through the ordering power held by "his goodly eyes" upon "the files and musters of the war"; and their decline has its nadir in the domestic and sexual abasements represented by "the bellows and the fan" (1.1.1-10) - as Shaw was memorably to put it, "a faithful picture of the soldier broken down by debauchery" (cit. Neill 1994: 69-70). This diagnosis is ostensibly confirmed in the same scene by Antony's own dictum, "not a minute of our lives should stretch/Without some pleasure now" (1.1.47-8), by his propensity to swear "for the love of Love and her soft hours" (1.1.45), and by his ensuing dismissal of the messenger, whose "news (...) from Rome" required deliberation and response $(1.1 .18,56)$. Further, this abstention from action and decision in the name of pleasure is apparently credited doubly to the two traits that in Aristotle explain the limitations of the akratic: impetuosity, as seen in Antony's impatience with the messenger; and weakness - to the extent that he yields to Cleopatra's discursive and histrionic manipulations with a proneness that later obtains an emblematic representation in Cleopatra's reminiscence of the couple's gender reversals: "I drunk him to his bed,/Then put my tires and mantles on him, whilst/I wore his sword Philippan" (2.5.21-3).

Antony's characterisation as a possible embodiment of akratic man is, however, more complex than these lines would suggest, since the character alternates, in the course of the play, between spectacular impairment of his capacity for rational decisionmaking and brooding, clear-headed assessment of his circumstance. The latter stance becomes manifest no later than 1.2, when Antony receives the messengers, acknowledges in soliloquy that "Ten thousand harms, more than the ills I know,/My idleness doth hatch", and replies to Enorbarbus's tellingly phrased, "What's your pleasure, sir?" with a curt, "I must with haste from hence" (1.2.135-9). Other occurrences of such (self-)awareness - or rather, of what Cleopatra refers to as "a Roman thought" (1.2.88) — see Antony rise to the political challenge posed by negotiations with (Octavius) Caesar in 2.2.; briefly regain, late in Act 4, those conditions for strategic command and military prowess (the loss of which Philo rued at 
the beginning) that allow him to be hailed again by a soldier as "brave emperor" (4.7.4); and offer, once everything is lost, that analysis of a fluid, cloud-like self, discontinuous with material form, that precedes his bid for an honourable, "Roman" death in 4.14.

Such moments, however, only highlight even more clearly the conditions that Antony paradoxically has for deliberating and following reason, rather than making options that audiences can identify as arising from wrong or (when impetuously made) non-reasoned choices that ultimately doom him, options that make him seem again and again (in Socratic terms) "inferior to himself" - the text is in fact punctuated by allusions to Antony becoming "short of that great property/Which still should go with Antony" (1.1.58-9). Indeed, his akratic profile derives additional density from the fact that the impulse to a realisation of agency that audiences can see as entailing effects contrary to Antony's own intents comes not just from his (permanent) "appetite for pleasure", but also from the other (tendentially incidental) vulnerability to passion that Aristotle detects as integrating the conditions for akrasia: anger.

In Antony's characterisation, anger may on occasion appear as indistinct from courage, that which, again in Philo's saying, made "his captain's heart" burst through any material boundaries. The major difference, however, is that Antony's bouts of anger fuelled by impetuosity, rather than by reasoning, diminish rather than magnify him denying him, therefore, that Mars-like or Herculean grandeur ("the demi-Atlas of this earth, the arm/And burgonet of men!" - 1.5.24-5) which Cleopatra so vocally celebrates. Again, a perception of this is enhanced by moments of self-awareness: "You'll heat my blood" (1.3.81), he cautions in a moment of impatience at Cleopatra's transparent manipulations; but it is especially damning that Antony's anger should, on some of its most debasing occasions, be aimed at a woman (Cleopatra), and/or take selfdenunciatory forms. This is the case when jealousy prompts him to level abuse at Cleopatra - "kite", "boggler" $(3.13 .94,115)$ — and order Caesar's fawning envoy to be brutally punished. The self-cancelling disproportion of his rage is signalled by Antony's own admission of ebbing power - "Authority melts from me" (3.13.95) - and by Enobarbus's remark on the dangers of "playing with (...) an old (...) dying [lion]" (3.13.99-100); while Antony's personal challenge is laughingly received by Caesar, who labels him an ineffectual "old ruffian" (4.1.4) and thus marks Antony's degradation from "triple pillar of the world" (1.1.12) to an embodiment of the miles gloriosus. The ultimate step in this self-abasing and bitterly ironical process comes with Antony's inability to kill himself in one stroke, which, following on his accusationcum-complaint to Cleopatra's eunuch — "O thy vile lady!/She has robbed me of my sword" (4.1.4.22-3) — reminds us of how often Antony's akratic shortcomings are represented through tropes of sex and gender.

Such implications suggest that the heuristic value of notions of akrasia for a critical consideration of tragic characters and agency, on the basis of a defining mismatch between intention and effect, can be productively tested also with regard to Shakespeare's Cleopatra. The challenges posed by female agency have long defined a relevant strand in the play's critical processing, but a discussion of the contradictions that mark this key female character as regards volition, action and achievement may 
enhance our understanding of how rich a dramatic construct Cleopatra can be, and of how that adds to the range of representations of human behaviour to be found in Shakespearean drama. The character's insight, in her brief discussion with Charmian in 1.3, into "the method" (1.3.8; which role to play, and how) to secure an emotional ascendant over the powerful men on her politico-sexual curriculum is a case in point for the intra-dramatic theatrical awareness so often to be found in Shakespeare. Since the dramatic framework for this key discussion consists of practical demonstrations of Cleopatra's ability to match action to desired effect, her metatheatrical savvy seems at this point to suggest that she might be an enkratic counterpoint to Antony's akrasia i.e., enjoying mastery over herself and her circumstance, and hence keeping passions from jeopardising balanced deliberation leading to reasoned choices. This possibility, however, is belied by an unfolding of the dramatic action that sees Cleopatra lose such mastery - and she does so, ironically, in ways that extend the metatheatrical theme.

Indeed, Cleopatra arguably exchanges an awareness of self that would entail a recognition of contingency, and her clear-headed immunity to the intra-dramatic shows that she staged them only for their effect on others, for gratifying fictions that may aim to obnubilate herself. Her treatment, in 2.5. and 3.3., of the messenger that brings news of Antony's marriage to Octavia amounts to the rejection of a plot and performance grounded on actuality (the messenger's truthful account in 2.5., for which he is harshly punished) in favour of a warped version of the actual (when the messenger is coerced by violence and bribed with gold to play a redrafted role and offer a representation of Octavia that can be accommodated in Cleopatra's narrative of her own glamorous, unrivalled womanhood). This moment of the plot can be read as evincing, again, a revealing concomitance of major conditions that otherwise might be alternatives in the delineation of an (Aristotelian) akratic profile (throughout Ethics VII: 1-10): the messenger's news is met in 2.5. by impetuosity, under the direct and uncontrolled influence of Cleopatra's passions, and reveal in 3.3. her weakness, when she deliberates and makes a choice (to recall the messenger) which nonetheless reflects a passion (vanity, self-love) rather than reason; and such akratic conditions are therefore revealed, consecutively, as prompted by anger (2.5) and appetite for pleasure (the pleasure of erotic self-regard - passim and 3.3).

Cleopatra's decisive role at the moment that marks a turning point in her and Antony's fortunes, the battle of Actium, both develops these conditions and confirms their gender implications, bound up with expectations of action vs. passivity. Military disaster follows Cleopatra's ill-reasoned deliberation to join the battle herself, or rather to "appear there for a man" (3.7.18); and her enthusiastic support of Antony's decision to fight Caesar "by sea, by sea" (3.7.40), against the advice of seasoned officers, and with herself on board "the Egyptian admiral" ship (3.10.2), quickly proves a decision against their own interests. The absence in the play of cogent reasons for the naval option makes it tempting to argue for vanity (again) as the mainspring for akratic behaviour, as if Cleopatra might envisage her presence on board her admiral ship at Actium as a sequel for her fabled appearance on her barge at Cydnus. However, a crucial difference as regards gendered agency determines a diverse outcome: if on 
Cydnus Cleopatra takes an initiative in self-staging (“o'erpicturing [...] Venus"), which operates through her becoming the object of a delighted universal "gaze" (2.2.210, 227), at Actium her assumption of an active warlike role (playing Mars) would require her to be the subject and source of the gaze - under the representational terms proposed by Philo from the first lines of the play, where the general's "goodly eyes" glow undaunted and imperiously "o'er the files and musters of the war" (1.1.2-3). Inability to do so makes Cleopatra flee the battle scene, with the destructive results that become (again visually) troped in the words of Enobarbus - the same who gave an eyewitness account of Cydnus now responding to Actium: "To see't mine eyes are blasted" (3.10.4).

The invective aimed at Cleopatra, at this point when the scene of her cowardly (womanly) flight from the battle makes her the object of visual loathing, rather than wonder and desire, is revealingly shown in animal terms: "Yon ribaudred nag of Egypt", "like a cow in June" $(3.10 .10,14)$. Such invective is profoundly ambivalent, redolent as it is of that joyful animalisation of the human that marked the literature of popular festivity and laughter ${ }^{2}$ while also inextricably bound up with the character's course towards catastrophe - her own and others'. Further cultural and literary associations can be carried by this construction of Cleopatra as an embodiment of the tension between (self-)mastery and incontinence (or loss of control), poised (as regards the reactions she obtains) between fascination for the "rare Egyptian" whom "age cannot wither", whose power to stimulate unsatiated desire "makes hungry/Where she most satisfies" $(2.2 .228,245-8)$, and revulsion at her debasing, bestialising powers, best glimpsed in the "monstrous" feasting provided at her Alexandrian court, where she "feed[s herself]/With most delicious poison" (1.5.27-8). Such traits —and such language - can indeed prove reminiscent of Edmund Spenser's Acrasia, the "false enchaunteresse" who, in Book II of The Faerie Queene, attracts knights to her "Bowre of blis", where "she makes her louers drunken mad", binds them "in chaines of lust and lewd desires" and turns them into beasts (II.1.51-4, II.12.84-5).

Despite the impression of obviousness conveyed by the character's name and description, the relevance of the Spenserian analogy to the concerns of this paper is rather limited. As the bane of "Temperaunce", Spenser's Acrasia stands for dissoluteness, "lewd loues, and wastfull luxuree" (II.12.80); and this, even if allegorically construed as epitomising a broader human proneness to temptation, is only one dimension in the range of forms that lack of self-mastery may acquire in the readings of tragic characters that I am here pursuing, informed by Plato's and Aristotle's disquisitions of akratic/enkratic behaviour. Further, Spenser's character remains firmly within the bounds of an allegorical framework in which her significance is fixed and immutable. This makes her quite unlike the evolving instabilities that define Shakespeare's representations of the human through the key characters in the tragedies in question, especially when they resume dramatic control and achieve greatness at the cost of self-destruction —while embodying that "radical individuation" that has been argued to mark Shakespeare's "startling departure from the norms of beauty that governed Renaissance taste" (Greenblatt 2010: 4-5). 
Cleopatra's reclamation of mastery over herself and her circumstance will only be realised through her suicide - which in her case (differently from Antony) allows her to fully match effect against intent. This, which is arguably the case with most tragic protagonists whose demise is self-inflicted, is certainly an element in common between the two tragedies here considered, also connected by the alterity that defines both Cleopatra ("gipsy" queen) and Othello (general and "blackamoor"). Additionally, the two tragedies highlight the cogency of gender expectations for an understanding of agency and akrasia; and they both show significant variations in self-control and selfawareness on the part of the main characters.

In the case of Othello, such variations are closely imbricated with the reasons for a rather evident distinction between Act I (as argued long ago by Susan Snyder, a small romantic comedy plot on its own - Snyder 1979: 70-90) and the rest of the play. Indeed, in Act I both Othello and Desdemona appear in full possession of themselves and their lot, matching volition and achievement, and the playwright emphasises this in a variety of ways. In the case of the title character, this is done in particular through that much-noted contrast between the traits that Iago ascribes to Othello in absentia, in his opening speech, and the characterisation defined by the Moor's first presence on stage (in 1.2). Iago famously describes Othello in 1.1 as "loving his own pride and purposes" - a formula that binds self-concern to heightened intentionality in the Moor's supposed character and behaviour - and suggests that such features are verbally matched by "a bombast circumstance/Horribly stuffed with epithets of war" (1.1.11-13). Conversely, the economy of word and action in Othello's first stage appearance suggests rather calm and ostensible modesty, which here become a badge of the character's mastery over himself and others; this is conveyed both through his concise response to Iago's provocative reporting of Brabantio's invective and his own assurances to his unwilling father-in-law, "you shall more command with years/Than with your weapons" (1.2.60$1)$.

Indeed, this very belief that an identity acknowledged as authoritative is more effective towards the attainment of one's goals than the incidentality of one's gestures and words, however forceful and cogent they may be, was previously manifested both to Iago and Cassio in Othello's references to the credit he expects to derive from "my services, which I have done the signiory", "My parts, my title and my perfect soul" $(1.2 .18,31)$. This is an expectation that the showdown at the Senate fully confirms, when a combination of reputation and measured words grants an (at this point) apparently enkratic Othello his intended effect - the social and legal validation of his elopement with Desdemona. Othello and Desdemona in fact converge in this, since the young woman's reasoned presentation of her case to the authorities equally proves her ability to match her forcefully assumed agency - elopement followed by fearless manifestation of her will in front of the Senate - to her intended effect. This is pointedly achieved over and above the authority of her own father, a Venetian Magnifico who appeals to the Duke and his peers only to hear his daughter demote his entitlements to a token share in her now "divided duty" (1.3.181). Desdemona proceeds to sealing her brief moment of mastery (promptly to be cancelled by wifely submission) 
by wresting from the Duke's "voice", in an arch-patriarchal environment, the "charter" that allows her to claim "the rites for which I love him" (martial? connubial?) and follow the husband she has chosen as he "go[es] to the war" $(1.3 .246,257-8)$.

However, and from this perspective, Othello and Desdemona might be seen as distinct characters for the rest of the play. Indeed, everything that happens in Othello from Act II onwards also provides a standpoint from which, retrospectively, the actions of the Moor and his bride in Act I (despite the immediate success they then obtained, or by contrasting such success with subsequent effects) might arguably be read as not reflecting reasoned choices, and in fact akratically working against the characters' own interests. It is not my purpose to revisit the rhetorical intricacies of Iago's corruption of Othello's judgement throughout the play (reviewing the critical attention that this has obtained would almost amount to charting the critical processing of the play from the Romantics to the present). I will merely add that Iago's effect on Othello offers a succession of demonstrations of how a character's passions can be activated to impair adequate reasoning, even on those occasions when Othello may seem to be weighing and deliberating, rather than acting impetuously under the effect of unprocessed emotions. Indeed, moments of ostensibly dispassionate assessment of self and circumstance — "Haply for I am black ..." (3.3.267) — seem to have a mitigating effect upon those other moments when Othello's discourse and/or action become (indeed) "incontinent", emotionally unbalanced and outright violent: "I will chop her into messes!" (4.1.197). Alternation between moments of one type and the other arguably allows the character to develop a sense of righteousness and justification, a belief in the rationality of his mental processes - "I'll see before I doubt, when I doubt, prove" (3.3.193) - and hence also the sense of justified and dignified outrage that leads him to construe Desdemona's killing as a "sacrifice" (for which he poses as controlled, enkratic high priest) rather than a "murder" (5.2.65).

Desdemona's case, in fact, may appear as a more enlightening object for critical application of the notion of akrasia, since context and rhetoric provide the means for audiences to perceive her decisions and actions in Cyprus as, in all likelihood, producing effects contrary to those she envisages. The beginning of the play's longest and most decisive scene, 3.3, sees Desdemona commit herself to Cassio's cause with a zest and assurance that can hardly be supported by the dramatic circumstance. Ostensibly, she listens, deliberates and only then makes promises — which might suggest that her akratic actions do not arise from impetuosity. However, as Cassio's would-be advocate regarding an issue (the loss of his lieutenancy) that previous passages in text and plot defined as sensitive - the play opens, after all, with echoes of the resentment caused by Cassio's appointment in the first place- Desdemona takes on a vicarious authority that she plainly cannot claim: "I give thee warrant of thy place" (3.3.20). This promise, made by an ageing general's young wife to his disgraced handsome lieutenant, might seem to belong within the range of a comic plot —in line, indeed, with such tales of sex and risible deceit as had prevailed in Italian reworkings of the Classical comic mould that left their imprint on Shakespeare, the Venetian background suggesting the cogency of Othello's wariness of Pantalone's inexorable fate 
(Salingar 1974: 189-90 and passim; Ellis 2009: 93-5 and passim). Indeed, the potential risibility and topsy-turveydom of Desdemona's assumption of a power that is "public" but nonetheless grounds itself on connubial and domestic prerogatives of bed and board is heightened by the itemisation of her programme: "My lord shall never rest,/I'll watch him tame and talk him out of patience,/His bed shall seem a school, his board a shrift,/I'll intermingle everything he does/With Cassio's suit" (22-6). In another dramatic framework, Desdemona's ensuing injunction - "be merry, Cassio" (26) might sound consensual and sharable, but the context and verbal realisation of her intentions endow them with an akratic crassness that validates rather the unwitting prescience of her closing words: "thy solicitor shall rather die/Than give thy cause away" (27-8).

The negative effects of Desdemona's intention and verbal action quickly unfold throughout this scene, which closes (nearly 400 lines later) with Othello confirming Iago rather as his lieutenant, and vowing death both to Cassio and "the fair devil" (481). The contrast between this and Desdemona's ability to match deliberation, action and speech to her intents in Act I - that ability, in her plea before the Senate, to get timing, register, and urgency right, thus securing the legal and social validation of her wishescould hardly be greater. Indeed, if one takes Desdemona's dramatic identity as established in Act I, then the rest of the play shows her akratically (in Socratic terms) always "inferior to herself". And if the matter of Cassio's lost lieutenancy involved compromise and power dynamics in the predominantly patriarchal world of action and public office, Desdemona's incapacity to understand the world of women as also including ethical uncertainties is equally displayed in her dialogue with Emilia in 4.3 (and could be taken as a case in point for the complexities attending on the much stressed notion of "Shakespeare's modernity in his treatment of women" - Dusinberre 1996: 5). Desdemona's wide-eyed naiveté — "Dost thou in conscience think (...)/That there be women do abuse their husbands (...) ?" (60-1) — proves strangely out of character coming from the young woman who had enough savvy to transgress against male authority and elope with the Moor into the Venetian night. Unless, of course, one judges the (un)reasoned nature of decisions leading to agency strictly on the basis of their final (rather than immediate) effects, and deems Othello and Desdemona's original transgression as the fundamentally akratic gesture that ultimately proves detrimental to its agents' best interests - i.e., the preservation of their lives.

The pathos of Desdemona's demise is undeniable, but it is strictly that of victimhood: the plot and text of Othello do not allow the play's main female character to be reclaimed to her former (ostensible, illusory?) mastery over self and circumstance. If a woman is endowed with that possibility in Othello it is rather Emilia — who, ironically, proved venal in her theft of the handkerchief, but knowledgeable about women and men in her dialogue with Desdemona in 4.3; indeed, her decision to rescue her mistress's reputation and memory from obloquy is matched by decisive verbal action that ensures the success of her intent - even at the cost of her own life. From this angle, Emilia, rather than Desdemona, anticipates Othello's final self-redemptive (and self-destructive) matching of intent, action and effect through word and sword - the 
weapons that proved ultimately of no avail to the disgraced akratic general in the other tragedy discussed above.

This discussion of perplexing discontinuities between intention and action in the representations of individual behaviour to be found in Antony and Cleopatra and Othello has focused on matters of plot and characterisation that have more often than not been tackled with conceptual tools developed within rather different frameworks. Traditionally, these have included and given pride of place to classical tragic theory, in particular when moulded on Aristotle's Poetics, which famously grounds the fallibility and inconsistency of human action on character flaws, leading to crucial error, assisted by hubris, and set off or accentuated by plot reversals or peripeteias. But the critical processing of the perplexities posed by agency in these Shakespeare tragedies has been decisively inflected by the centrality of their key characters to the reconfiguration of Shakespearean criticism, since the final quarter of the twentieth century, under the impact of critical models based on gender and ethnicity - and this in an intellectual environment largely formatted by the altered rapport of text and context that defined what twenty years ago could generically be called "the new contextualisms" (Felperin 1990: vi and passim).

The discussion above, conceptually driven as it is, does not propose itself as a regressive instance of a criticism grounded on a sense of immutable human nature, a criticism striving for the ahistorical and apolitical; on the contrary, it is supported at all points by an awareness that the gap between volition and agency on which it focuses has its depth of meaning and potential pathos extended by a sense of the contingencies and iniquities of history and power. It is such an awareness that allows for Roman denunciations of Antony's transgressiveness and Cleopatra's crafty manoeuvring themselves existing in a tension between the akratic and the enkratic - to be read as issuing from the same gender typecasting; for Othello's transit from enkratic assurance to akratic, uncontrollable rage to be perceived as the Moor's inexorable demotion to the negative racial profile of which, at the outset, he was proudly and pointedly the opposite; and for the near commutation of Desdemona's and Emilia's respective akratic/enkratic selves to be seen as shedding light on women's strife to propel character beyond circumstance - which also means, beyond the risible or despicable traits of female dramatic types (between naiveté and venality).

Such insights can be extended and consolidated when the challenges faced by the central characters in these tragedies are considered in the light of a problem that has energised discussions of human agency since antiquity - the perplexity posed by contradictions between the shape and content of one's decisions and their achieved effects, in the light of one's interests and goals. Taking the instances of human singularity afforded by Antony and Cleopatra and Othello, indeed prominent cases of early modern "radical individuation" (Greenblatt 2010: 5), and discussing them from the perspective of akrasia, pointedly validates the intellectual longevity of this notion; but it no less emphatically confirms the continued (however variable and evolving) imaginative consequence of Shakespeare's representations of human experience. 


\section{Notes}

1. Though first published in 1954, Madeleine Doran's Endeavors of Art remains possibly, in her section on the de casibus tradition, the clearest disquisition on the topic since the midtwentieth century (1964: 116-28); for more recent studies, see Budra 2000: 15-16 and passim; Kastan 2007: 7-8; and Pincombe 2010: 3-6.

2. As abundantly proved, over the past three decades, in the many studies of early modern writing that have derived their conceptual framework from Mikhail Bakhtin's influential Rabelais and His World ([1965] 1984).

\section{References}

Primary:

Aristotle (1908): Nichomachean Ethics. Translated W. D. Ross. Oxford: Clarendon Press. (online transcript at http://classics.mit.edu/Aristotle/nicomachaen.mb.txt; last accessed 25/09/2012).

Aristotle (1895): The Poetics of Aristotle, trans. with a critical text by S.H. Butcher. London and New York: Macmillan. Online transcript at:

http://archive.org/stream/poeticstranslate00arisuoft\#page/n5/mode/2up last accessed 25/09/2012)

Plato (1892): The Dialogues of Plato, trans. into English with analyses and introductions by B. Jowett in 5 vols, $3 \mathrm{~d}$ edition. London: Oxford U.P. Online facsimile at: http://oll.libertyfund.org/index.php?option=com_staticxt\&staticfile=show.php\%3Ftitle=111 \&Itemid=27; last accessed 25/09/2012)

Shakespeare, William (1995): Antony and Cleopatra, John Wilders, ed. The Arden Shakespeare [3]. London: Routledge.

Shakespeare, William (1994): Antony and Cleopatra, Michael Neill, ed. Oxford: O.U.P.

Shakespeare, William (1997): Othello, E.A.J.Honigmann, ed. The Arden Shakespeare [3]. London: Thomson.

Spenser, Edmund (1987): The Faerie Queene, Thomas P.Roche, Jr. and C.Patrick O'Donnell, Jr. eds. London: Penguin.

Secondary:

Alexander, Catherine M.S. and Stanley Wells, eds. (2000): Shakespeare and Race. Cambridge: C.U.P.

Bakhtin, Mikhail (1984): Rabelais and His World (1965). trans. Hélène Iswolsky. Bloomington, Indiana U.P.

Budra, Paul (2000): A Mirror for Magistrates and the de casibus Tradition. Toronto: University of Toronto Press.

Doran, Madeleine (1964): Endeavors of Art: a study of form in Elizabethan drama (1954). Madison, Wis: Univ. of Wisconsin Press.

Drakakis, John and Naomi Conn Liebler, eds. (1998): Tragedy. Harlow: Longman. 
Dusinberre, Juliet (1996): Shakespeare and the Nature of Women, $2^{\text {nd }}$ edition. Houndmills: Macmillan.

Ellis, Anthony (2009): Old Age, Masculinity and Early Modern Drama: Comic Elders on the Italian and Shakespearean Stage. Farnham: Ashgate.

Felperin, Howard (1990): The Uses of the Canon: Elizabethan Literature and Contemporary Theory. Oxford: Clarendon Press.

Greenblatt, Stephen (2010): Shakespeare's Freedom. Chicago and London: The University of Chicago Press.

Jankowski, Theodora (1992): Women in Power in the Early Modern Drama. Urbana and Chicago, Ill.: University of Illinois Press.

Kastan, D. S. (2007): “"A rarity most beloved": Shakespeare and the Idea of Tragedy, R.

Dutton and J. E. Howard, eds., A Companion to Shakespeare's Works, Volume 1: The Tragedies. Oxford: Blackwell. 4-22.

Loomba, Ania (1989): Gender, Race, Renaissance Drama. Manchester: Manchester U.P.

Pincombe, Mike (2010): 'English Renaissance Tragedy: theories and antecedents', Emma Smith and Garrett A.Sullivan, eds., The Cambridge Companion to English Renaissance Tragedy. Cambridge: C.U.P. 3-16.

Salingar, Leo (1974): Shakespeare and the Traditions of Comedy. Cambridge: C.U.P.

Snyder, Susan (1979): The Comic Matrix of Shakespeare's Tragedies. Princeton. N.J.: Princeton U.P.

Taylor, Michael (2001): Shakespeare Criticism in the Twentieth Century. Oxford: O.U.P. Vaughan, Virginia Mason (1994): Othello: A Contextual History. Cambridge: C.U.P. 